\title{
Analysis of Physics University Students' Knowledge and Understanding of Thermodynamic Scientists
}

\author{
R A R Yovan ${ }^{1}$, I S Ningsari ${ }^{1}$, A K Sukma ${ }^{1}$, Y N Qomariah ${ }^{1},{ }^{*}$ H N Hidaayatullaah ${ }^{2}$ \\ 1Department of Physics, Faculty of Mathematics and Natural Science, Universitas Negeri Surabaya, Surabaya 60231, \\ Indonesia \\ 2Postgraduate Program of Science Education, Universitas Negeri Surabaya, Surabaya 60213, Indonesia
}

\begin{tabular}{l} 
Article Info \\
Article history: \\
Received March 21, 2021 \\
Revised May 05, 2021 \\
Accepted May 21, 2021 \\
Available Online May 24, 2021 \\
\hline
\end{tabular}

Keywords:

Scientist

Thermodynamics

Understanding

Knowledge

\begin{abstract}
This study aims to determine the knowledge and understanding of physics students related to thermodynamic scientists. This research method is descriptive quantitative and qualitative. Collecting data using a google form-based test instrument with 3 levels of questions on six scientist figures, namely Joseph Black, Robert Boyle, Joseph Louis Gay Lussac, Sadi Carnot, James Presscout Joule, and Gabriel Fahrenheit. The subjects of this research were students of physics at the State University of Surabaya in levels one and two who had taken basic physics courses. Based on research data, the percentage of respondents understanding related to thermodynamics, namely $12 \%$ did not know thermodynamics scientists, $24 \%$ only knew thermodynamics scientists, $40 \%$ understood the concept of thermodynamic scientists sufficiently, $24 \%$ understood the concept and could explain the concept of thermodynamic scientists findings as a whole. University students' knowledge and understanding related to thermodynamic scientists are mostly at the level of understanding. The most widely known figure of thermodynamic scientists and the concept of the most widely understood is Robert Boyle and the most unknown is Joseph Louis Gay Lussac.
\end{abstract}

\section{INTRODUCTION}

Physics is the study of natural phenomena and the environment. Therefore, Physics is called a branch of Natural Science or Science. Meanwhile, a physicist studies the behavior and properties of matter in a very diverse field, from the submicroscopic particles that make up all matter to the behavior of the matter in the universe as a unitary cosmos. Some of the properties studied in physics are properties that exist in all material systems, one of which is Thermodynamic matter. This kind of property is called the law of physics (Hidaayatullaah et al., 2020; Festiana, 2018).

The history of physics is very important to study, especially the history of physical scientists. Because by knowing a lot of history, knowledge will be broader, and maybe even from these histories can find discoveries that might improve previous discoveries. Even in the undergraduate physics education program at State University of Surabaya, the subject of physics history is a subject that has become a trend of student interest, even though it is a selective subject (Efendi et al., 2020; Suprapto \& Dwikoranto, 2011).

Philosophy can be understood if the reflection on the history of science is understood. Therefore, it is important to know the process of scientific development in its historical context to obtain a thorough understanding. It is also necessary to understand philosophical and 
scientific issues. In particular, there are major issues regarding natural philosophy and its development and changes during its more than 2500 years of history (Sinensis, 2017)

Learning physics only explains theories, concepts, and formulas. The introduction of the inventor is not overly emphasized. The history of physics emphasizes the introduction of physics figures, their work, and their findings (Tora, 1999). Through the introduction of this figure, he can provide more in-depth knowledge regarding how the scientist's initial thinking in finding a theory or other findings. From this, it can provide comprehensive and more in-depth knowledge regarding the concepts and theories found.

The theory of heat first developed in the 18th century, but only began to develop rapidly in the 19th century. The development of heat theory can be viewed from two aspects, namely in terms of mechanics and aspects of heat (Abdullah, 2016). On January 25, 1627 Robert Boyle was born in the Irish City of Waterford. Robert Boyle is an Irish scientist, philosopher, physicist, and chemist. Robert Boyle measured the properties of a gas in a state close to that of an ideal gas. Boyle concluded that at a constant temperature the volume of a gas is inversely proportional to its pressure. Better known as Boyle's Law (Giancoli, 2001; Soepri, 2011).

The next scientist, Daniel Gabriel Fahrenheit was born on May 24, 1686. He is a physicist, inventor, and maker of scientific instruments. In 1724 he managed to find the measurement scale that is used today. This scale is known as the Fahrenheit scale. The next is scientist Joseph Black was born April 16, 1728 and died December 6, 1799. He was known as a physicist. 1760 Black put forward the principle of the Black Principle. The Black principle reads "If two kinds of substances with different temperatures are mixed, then the substance with a higher temperature will release as much heat as the heat absorbed by a substance with a lower temperature" (Mikrajuddin, 2016).

The next is Joseph Louis Gay Lusac was born on December 6, 1778. He is a scientist from France. In the field of Thermodynamics, he contributed to the Gay-Lusac Law. Gay-Lussac observed changes in gas pressure at varying temperatures by making the gas volume fixed. From there Gay-Lussac concluded. At a fixed volume, the pressure of a gas is directly proportional to its temperature (Crosland, 1978; Mikrajuddin, 2016).

Sadi Carnot, the son of Lazare Carnot, was born on June 1,1796, at the age of 16, Carnot studied at Ecole. Carnot graduated in 1814 after graduating. Carnot continued at the Ecole du Genie at Metz and spent two years studying military engineering. Sadi's first papers he wrote in 1822-1823 contained mathematical expressions for calculating steam engine power. Sadi's work is recognized as the clearest, most thorough, and easy to understand. In 1824, Carnot published a book entitled "Reflexions sur la puissance motrice du feu at sur les machine propres a developper cette puissance." This book was the first and last book by Carnot. This book explains the "Carnot Cycle", the Carnot Cycle consists of an isothermic process and an adiabatic process (Zemansky, 1965).

James Prescott Joule is a British scientist who formulated the Law of Conservation of Energy, which is "Energy can neither be created nor destroyed." He was born on March 21, 1768. At the age of 17 Joule entered the University of Manchester under the guidance of Jhon Dalton. Joule published a book entitled About Heat Generated by Electricity in 1840 at the age of 22. After that in 1843, he published another book on the mechanical equivalent of heat. For the next four years to be precise in 1847 he published a book on the relationship and conservation of energy. The law of conservation of energy is one of the laws of conservation that includes kinetic energy and potential energy. The Law of Conservation of Energy (Law I of Thermodynamics) reads: "Energy can change from one form to another but cannot be created or destroyed or called energy conversion" (Cardwell, 1991).

Based on the description, the focus of the material used to express students' understanding and knowledge of scientists is thermodynamics. The purpose of this study was to determine the knowledge and understanding of physics students related to thermodynamic scientists. The results of this study can then be used as material for consideration to carry out preventive 
action and to overcome the lack of understanding of scientists and thermodynamic concepts in students in learning physics.

\section{RESEARCH METHOD}

This research uses descriptive quantitative and qualitative methods. The main reason is "to get an overview of the knowledge and understanding of physics university students about thermodynamics scientists and their discovery of concepts by these scientists". Data collection was carried out for 1 month, starting from April to May 2020. The research process was carried out by compiling a google form-based test instrument, an assessment instrument by experts and researchers.

\section{Respondents}

Respondents that had been planned were 70 physics university students, but the respondents in this study were 45 physics students at the State University of Surabaya. Data were collected by purposive sampling with the characteristics of the subject are students in levels 1 and 2 who are taking and have taken basic physics 2 because in basic physics 2 thermodynamics has been discussed. For small sample sizes using the Slovin formulation with an error margin of 0.1 $(10 \%)$.

$$
\mathrm{n}=\frac{N}{\left(1+N e^{2}\right)}
$$

From the above equation, $\mathrm{n}$ is the minimum number of samples, the value of $\mathrm{N}$ is the population while the value of e is the error margin. So, $n=70:(1+70 \times 0.01)=41.17$. Therefore, for respondents 50 university students are sufficient by the Slovin formula.

\section{Instruments}

The data collection technique used a test instrument with 3 levels of questions, namely: (1) knowing about the scientist with two choices, yes or no; (2) what concept was found; (3) describe the concepts found by the understanding of six thermodynamic scientists. For data analysis, it can be interpreted in the following table:

Table 1. Table of knowledge and understanding levels

\begin{tabular}{|c|c|c|}
\hline Number & $\begin{array}{c}\text { Level of Knowledge and } \\
\text { Understanding }\end{array}$ & Information \\
\hline 1 & Understand & Knowing, mentioning concepts, describing concepts \\
\hline 2 & Enough understand & $\begin{array}{l}\text { Knows, mentions concepts but cannot describe } \\
\text { concepts or misrepresentations of concepts }\end{array}$ \\
\hline 3 & Just knowing & $\begin{array}{l}\text { Knows but cannot state the concept or describe the } \\
\text { concept }\end{array}$ \\
\hline 4 & Do not know & Don't know anything \\
\hline
\end{tabular}

\section{RESULTS AND DISCUSSION}

From the research conducted, data was obtained in the form of respondents' understanding of thermodynamic scientists, and their findings were classified into 4 levels of understanding, namely not knowing, only knowing, understanding concepts, being able to explain concepts. The scientists referred to are six scientists, namely Joseph Black, Sadi Carnot, Robert Boyle, Joseph Louis Gay-Lussac, James Prescott Joule, and Gabrielle Fahrenheit. By testing 45 respondents, it can be interpreted in table 2 of the data regarding the understanding of university students majoring in physics at the first and second levels of thermodynamics scientists. 
Table 2. Respondents' result data

\begin{tabular}{|c|c|c|c|c|c|c|c|}
\hline $\begin{array}{c}\text { Level of } \\
\text { Knowledge and } \\
\text { understanding }\end{array}$ & $\begin{array}{l}\text { Joseph } \\
\text { Black }\end{array}$ & $\begin{array}{c}\text { Sadi } \\
\text { Carnot }\end{array}$ & $\begin{array}{l}\text { Robert } \\
\text { Boyle }\end{array}$ & $\begin{array}{c}\text { Gay } \\
\text { Lussac }\end{array}$ & $\begin{array}{l}\text { Prescott } \\
\text { Joule }\end{array}$ & $\begin{array}{c}\text { Gabriele } \\
\text { Fahrenheit }\end{array}$ & Total \\
\hline Do not know & 3 & 7 & 7 & 8 & 3 & 4 & 32 \\
\hline Just know & 7 & 9 & 8 & 10 & 14 & 17 & 65 \\
\hline $\begin{array}{c}\text { Simply } \\
\text { Understand the } \\
\text { Concept }\end{array}$ & 16 & 20 & 19 & 18 & 19 & 17 & 109 \\
\hline $\begin{array}{c}\text { Understand the } \\
\text { Concept }\end{array}$ & 17 & 4 & 22 & 8 & 10 & 3 & 64 \\
\hline \multicolumn{3}{|c|}{ Most Understanding of the Concept } & \multicolumn{2}{|c|}{ : Robert Boyle } & & & \\
\hline \multicolumn{3}{|c|}{ At least understand the concept } & : Fahrenh & & & & \\
\hline \multicolumn{8}{|c|}{ Most Sufficiently Understand the Concept : Sadi Carnot } \\
\hline \multicolumn{3}{|c|}{ At least understand the concept } & \multicolumn{3}{|c|}{ : Joseph Black } & & \\
\hline \multicolumn{3}{|c|}{ Most Only Know } & \multicolumn{3}{|c|}{ : Prescott Joule } & & \\
\hline \multicolumn{3}{|l|}{ Least Only Knows } & \multicolumn{3}{|c|}{ : Joseph Black } & & \\
\hline \multicolumn{3}{|c|}{ Most don't know } & \multicolumn{3}{|c|}{ : Gay Lussac } & & \\
\hline \multicolumn{3}{|c|}{ At least don't know } & \multicolumn{3}{|c|}{ : Joseph Black dan Prescott Joule } & & \\
\hline
\end{tabular}

From table 2, we can see how the respondent's level of understanding regarding physicists and their findings, if the upper and lower limits are taken, the scientist who is best known and whose concept is fully understood by the respondent is Robert Boyle, while the scientist most unknown is Joseph Louis Gay Lussac. From this interpretation, we can analyze the causes of what happened. When associated with the curriculum applied in high school (SMA) in physics, the scientists who were introduced directly and the theory were Sadi Carnot regarding the Carnot Cycle, then Joseph Black through the Black Principle, Robert Boyle and Gay Lussac on Ideal Gas. These theories are also widely applied to several tools that exist in everyday life, and many teachers also apply learning media to facilitate students in understanding thermodynamic concepts about the relationship of pressure, volume, and temperature. Such as research conducted by Gusmida \& Islami (2017) states that the development of learning media for kinetic gas theory with Augmented Reality is of high quality and suitable as a complementary medium in learning on the kinetic gas theory which is an abstract topic.

Whereas Prescott Joule in learning is mostly taught only in units, and Fahrenheit through units of temperature and thermometer. From here we see the results of the respondent's understanding which is a physics student class 1 and 2 at the State University of Surabaya who can better explain the concept put forward by Robert Boyle, this can happen due to several factors, including

1. The concept put forward by Robert Boyle is easy to understand.

2. The concept put forward by Robert Boyle is fundamental.

3. High school thermodynamic physics learning emphasizes the concepts put forward by Robert Boyle (Ideal Gas).

However, of the 3 factors, if one of them can support why the results that come out of this study are as interpreted, of course there are related irregularities where one of the scientists who has a fundamental concept is Joseph Black, but these data show that Joseph Black is a scientist who has data at least understand concepts and at least only knows. So that it shows the respondent knows who Joseph Black is, but has a deficiency in understanding the concepts put forward. From here, of course, it can be used as an evaluation regarding the process of delivering material and explaining the concept of thermodynamics in high school. From these data, it can also be seen that the only scientist who is known to the most is Prescott Joule, who put forward the concept of conservation of energy. It can be seen from the answers given, several factors may be the cause, among others 
1. Respondents only often heard the name Joule but did not know what concept was being put forward.

2. Learning in high school does not emphasize that the concept put forward by Joule is the conservation of energy

3. Learning in high school related to energy conservation is less able to provide understanding to students.

From here, of course, it can be mapped the material which is still less understood by students at the time of learning in high school through analysis associated with the name of the scientist who argued.

If we look at the total level of understanding of the respondents, there is a value of understanding the concept with 109 points. This interprets that some students of physics level 1 and 2 of Surabaya State University have understood the concept of thermodynamics when viewed from the recognition of scientists' names. Or when interpreted in a pie diagram

\section{Total Respondents' Understanding Regarding Thermodynamics}
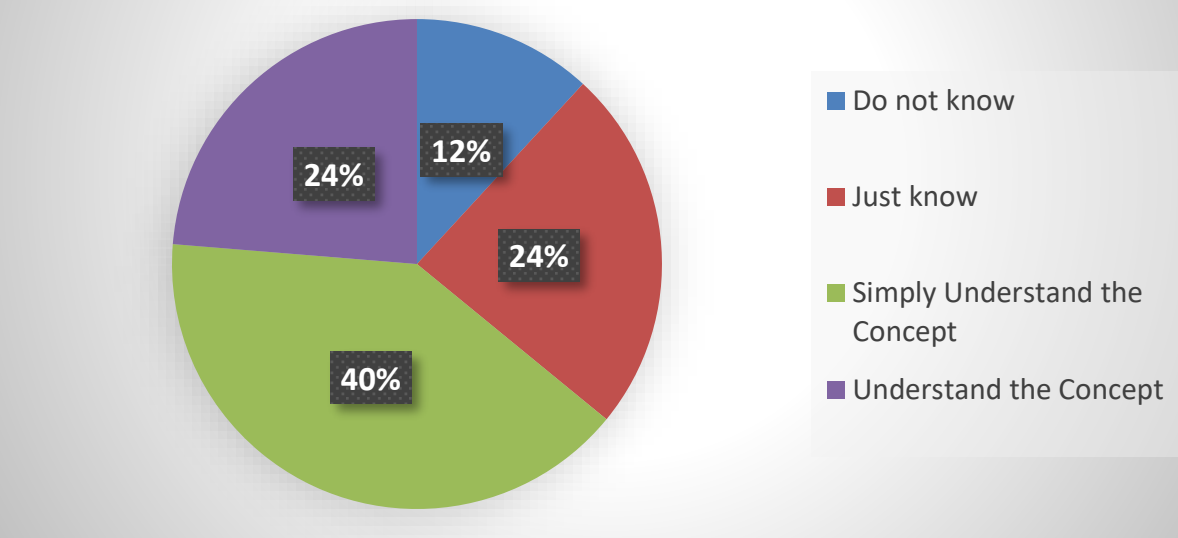

Figure 1. Pie diagram of the respondent's total understanding of thermodynamics

From this, it can be seen that only $12 \%$ of respondents do not know about thermodynamic scientists and $40 \%$ are sufficiently aware of the concept and can state the concept as a whole.

Seeing this happen, we can determine that telling the name of the scientist who put forward the concept of thermodynamics being studied is important to improve the understanding and knowledge of high school students later so that when they enter college they can clearly understand and know who the scientist proposed.

\section{CONCLUSION}

Based on the research data, it can be concluded that the respondent's understanding of thermodynamics, namely $12 \%$ of respondents did not know about scientists, and $40 \%$ had sufficient understanding and could mention the concept of scientists' findings related to thermodynamics. And the scientist who is best known and whose concepts are well understood by students of physics at the Surabaya State University level one and two is Robert Boyle, while the most unknown scientist is Joseph Louis Gay Lussac.

\section{ACKNOWLEDGEMENTS}

Thank you to Mr. Nadi Suprapto Ph.D. as the supervisor of the writing of this research article and friends of physics students of Surabaya State University level 1 and 2 who have been willing to become respondents in this study. 


\section{REFERENCES}

Abdullah, M. (2016). Fisika dasar I . Institut Teknologi Bandung.

Cardwell, D. S. L. (1991). James Joule: A biography. Manchester University Press.

Crosland, M. (1978). Gay-Lussac, scientist and bourgeosis. Cambridge University Press.

Efendi, M. Y., Cheng T-H., Sa'diyah E. H., Wulandari, D., Qosyim, A., \& Suprapto, N. (2020). Study of the implementation of Socratic dialogue at history of physics course. Studies in Philosophy of Science and Education, 1(2), 7-20. https://doi.org/10.46627/sipose.v1i1.7

Festiana, I. (2018). Perkembangan eksperimen fisika ditinjau dari filsafat sains. Jurnal Inovasi Fisika dan Riset Ilmiah, 2(1), 14-20. https:/ / doi.org/10.30599/jipfri.v2i1.147

Giancoli, D. C. (2001). Physics principles with aplication. Pearson Prentice Hall.

Gusmida, R., \& Islami, N. (2017). The development of learning media for the kinetic theory of gases using the ADDIE model with augmented reality. Journal of Educational Sciences. 1(1), $1-10$.

Hidaayatullaah, N. H., Dwikoranto, Suprapto, N., Mubarok, H., \& Wulandari D. (2020). Implementation of problem based learning to train physics students' problem solving skills. Journal of Physics: Conference Series, 1491(012053).

Mikrajuddin. (2016). Fisika dasar 1. Institut Teknologi Bandung.

Sinensis, A. R. (2017). Sejarah filsafat sains sebagai pendekatan dalam pembelajaran fisika pada konsep Archimedes. Jurnal Inovasi Pendidikan dan Riset Ilmiah, I, 23-28.

Soepri. (2011). Robert Boyle kimiawan modern. PT Gramedia.

Suprapto, N., \& Dwikoranto. (2019). Sejarah fisika untuk universitas (2nd ed.). JDS.

Suprapto, N., \& Dwikoranto. (2011). Development of learning materials with Socratic model at history of physics. Jurnal Penelitian Fisika dan Aplikasinya, 1(1), 14-22.

Tora, R. L. (1999). Sumbangan sejarah fisika dalam pembentukan sikap dan nilai. Jurnal Fisika Indonesia, 3, 318-324.

Zemansky, M. W., \& Dittman, R. H. (1965). Heat and thermodynamics (7th ed.). The McGraw-Hill Companies, Inc.

\section{Author (s):}

Ricki Angga Rizti Yovan

Department of Physics, Faculty of Mathematics and Natural Science,

Universitas Negeri Surabaya,

Jl. Ketintang, Surabaya 60231, Indonesia

Email: rickijr87@gmail.com

Intan Sumarak Ningsari

Department of Physics, Faculty of Mathematics and Natural Science,

Universitas Negeri Surabaya,

Jl. Ketintang, Surabaya 60231, Indonesia

Email: intan.sumarak@gmail.com

Adhelia Karunia Sukma

Department of Physics, Faculty of Mathematics and Natural Science,

Universitas Negeri Surabaya,

Jl. Ketintang, Surabaya 60231, Indonesia

Email: Aksadhelia@gmail.com

Yuyun Nailul Qomariah

Department of Physics, Faculty of Mathematics and Natural Science,

Universitas Negeri Surabaya,

Jl. Ketintang, Surabaya 60231, Indonesia

Email: yuyunnailul7@gmail.com 


\footnotetext{
* Hasan Nuurul Hidaayatullaah (Corresponding Author)

Postgraduate Program of Science Education

Universitas Negeri Surabaya,

Jl. Lidah Wetan, Surabaya 60231, Indonesia

Email: hasannuurulh@gmail.com
} 